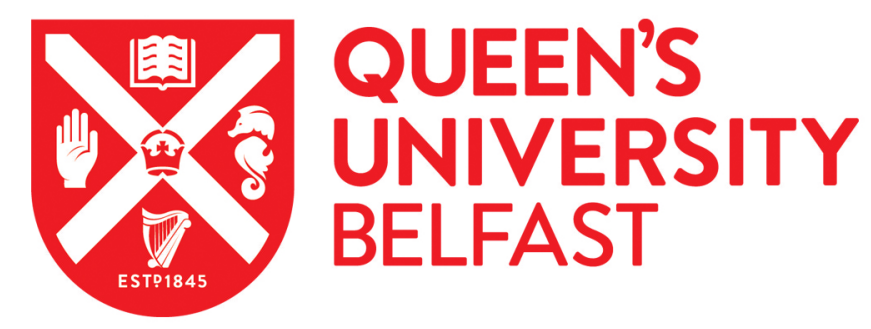

\title{
Criminal Justice, Truth Recovery and Dealing with the Past in Northern Ireland
}

Lawther, C. (2015). Criminal Justice, Truth Recovery and Dealing with the Past in Northern Ireland. In A-M. McAlinden, \& C. Dwyer (Eds.), Criminal Justice in Transition: The Northern Ireland Context Hart.

http://www.hartpub.co.uk/books/details.asp?isbn=9781849465779

\section{Published in:}

Criminal Justice in Transition: The Northern Ireland Context

\section{Document Version:}

Peer reviewed version

Queen's University Belfast - Research Portal:

Link to publication record in Queen's University Belfast Research Portal

\section{Publisher rights}

(C) 2015 Hart Publishing.

This work is made available online in accordance with the publisher's policies. Please refer to any applicable terms of use of the publisher.

\section{General rights}

Copyright for the publications made accessible via the Queen's University Belfast Research Portal is retained by the author(s) and / or other copyright owners and it is a condition of accessing these publications that users recognise and abide by the legal requirements associated with these rights.

Take down policy

The Research Portal is Queen's institutional repository that provides access to Queen's research output. Every effort has been made to ensure that content in the Research Portal does not infringe any person's rights, or applicable UK laws. If you discover content in the Research Portal that you believe breaches copyright or violates any law, please contact openaccess@qub.ac.uk. 
In: Criminal Justice in Transition. Eds: McAlinden, A-M. and Dwyer, C. (London: Hart, 2015: 27-46).

\title{
CRIMINAL JUSTICE, TRUTH RECOVERY AND DEALING WITH THE PAST IN NORTHERN IRELAND
}

\author{
Cheryl Lawther
}

\section{Introduction}

During the Northern Ireland conflict more than 3,700 individuals were killed and 40,000 injured (McKittrick et al, 2007). Reflecting broader international trends, there has been much discussion on how Northern Ireland should deal with its past and, in particular, the recovery of truth about past human rights violations - now considered an axiomatic element of post-conflict reconstruction (see for example: WiebelhausBrahm, 2010; Hayner, 2011). ${ }^{1}$ Setting Northern Ireland apart however, is the absence of a formal truth recovery process. Unlike many other 'post-conflict' societies, truth recovery was not a part of the Belfast Agreement in 1998. Rather, during the negotiations, a premium was placed on avoiding anything as contentious and potentially divisive as a truth commission (Bell, 2003; Lundy, 2010). Instead, issues that in other circumstances might have fallen under the remit of a truth commission (the reform of the police, a review of the criminal justice system, prisoner releases and so forth), were disaggregated and addressed separately and distinctly (Bell, 2003; O'Rawe, 2003; Lundy, 2010).

That said, legacy issues have loomed large on Northern Ireland's social and political landscape and there have been consistent calls for a full examination of the past. There have been two significant junctures in this debate. First was the establishment of the Consultative Group on the Past (CGP) by the British government in June 2007. The Group reported in January 2009 and recommended that a Legacy Commission - a bespoke truth mechanism shaped around the themes of 'Review and Investigation', 'Information Recovery' and 'Thematic Examination' be established

\footnotetext{
${ }^{1}$ Misztal (2003: 147) argues that 'coming to terms with the past has emerged as the grand narrative of our times'.
} 
In: Criminal Justice in Transition. Eds: McAlinden, A-M. and Dwyer, C. (London: Hart, 2015: 27-46).

(CGP, 2009). ${ }^{2}$ This proposal and the remainder of the CGP's report subsequently faltered and fell on the recommendation that a $£ 12,000$ 'Recognition Payment' would be paid to all victims of the conflict - civilians, members of the security forces and former members of paramilitary organizations (CGP, 2009). ${ }^{3}$ Second and more recently, the former US envoy to Northern Ireland, Dr. Richard Haass and Professor Meghan O'Sullivan were appointed in July 2013 to chair an all-party group designed to facilitate discussion on issues relating to flags and emblems, parades and the past (Northern Ireland Office, 2013). Following six months of meetings and negotiations and over 600 submissions, Haass and O'Sullivan made their final recommendations on 30 December 2013. On the past, they include a Historical Investigations Unit (HIU) which would pull together the Historical Enquiries Team (HET) and the Office of the Police Ombudsman for Northern Ireland (OPONI) and, backed by appropriate powers, would investigate outstanding cases, with a view to prosecution where possible; an Independent Commission for Information Retrieval (ICIR), which would have the power to offer limited immunity from prosecution in return for truth recovery, and would include an internal unit designed to analyse patterns and themes related to the conflict; and other processes to facilitate acknowledgement, storytelling and specialist services for victims and survivors (Haass and O'Sullivan, 2013). The talk's process failed to reach agreement on any of the three issues by the deadline of 31 December 2013 (BBC, 2013a). In this vacuum, the criminal justice system has become the space wherein victims and survivors have sought 'truth' and contested versions of the past have been examined.

This chapter engages with Northern Ireland's 'piecemeal' approach to the past to critically examine the capacity and limitations of 'ordinary' criminal justice in a 'transitional' context (Bell, 2003: 1095). The structure of this chapter is as follows: The first part explores the rationale for 'truth recovery' in the aftermath of violent conflict and provides a broad overview of the key truth-finding mechanisms at play.

\footnotetext{
${ }^{2}$ See the Report of the Consultative Group on the Past for full details on these strands (CGP, 2009).

${ }^{3}$ This payment was to be awarded on the basis of the inclusive Victims and Survivors (Northern Ireland) Order 2006. It provides the statutory definition of a victim or survivor of the conflict as '(a) someone who is or has been physically or psychologically injured as a result of or in consequence of a conflictrelated incident; (b) someone who provides a substantial amount of care on a regular basis for an individual mentioned in paragraph (a); or (c) someone who has been bereaved as a result of or in consequence of a conflict-related event'. Available at: www.opsi.gov.uk/si/si2006/20062953.htm (accessed 28 May 2014). ED NOTE - USE STYLE AS TEMPLATE
} 
In: Criminal Justice in Transition. Eds: McAlinden, A-M. and Dwyer, C. (London: Hart, 2015: 27-46).

These include the police-led Historical Enquiries Team (HET), the Office of the Police Ombudsman for Northern Ireland (OPONI), public inquiries, the inquest system, the Criminal Cases Review Commission (CCRC) and litigation by victims and former combatants. The remainder and main part of the chapter explores the intersection between these elements of the criminal justice system and dealing with the past. It argues that the Northern Ireland experience speaks to four key themes in the transitional justice literature concerning the limitations of legalistic variants of truth recovery, the meaning of accountability, the ways in which hierarchies of victims are created and sustained and the capacity of victims and former combatants. Each is explored in turn. This chapter concludes by arguing that while the criminal justice system has played an important role in dealing with the legacy of the past in Northern Ireland, it was neither designed to, nor is it capable of offering a full examination of the causes, context or consequences of the Northern Ireland conflict. Rather, its inherent limitations have resulted in an approach to the past that is piecemeal, incomplete and marked by significant shortcomings.

\section{Truth, Transition and Dealing with the Past}

The reasons why a transitional society may choose to 'deal with' its past, typically by seeking truth about past human rights violations, through, for example, a truth commission, commission of historical clarification or criminal trials, are well established. Lundy and McGovern (2008: 178) argue that 'dealing with the past' is generally taken to refer to three interrelated areas of concern. First, how public memory or commemoration of the past, or processes designed to clarify the historical record, might contribute to positive social change or 'reconciliation' in a violently divided society. Second, how the victims or survivors of the conflict and their relatives can be provided with various forms of support or offered opportunities to come to terms with past experiences. Third, what means (either judicial or non-judicial) might be introduced to deal with outstanding truth and justice issues and provide a record of past human rights abuses. Other cross-cutting objectives include reaffirming the rule of law; making known the range of forensic, personal and social 'truths' about past conflict; and broadening ownership of the structural causes of violence and conflict transformation (Tutu, 1999; Boraine, 2000; Smyth, 2007; Wiebelhaus-Brahm, 2010). 
In: Criminal Justice in Transition. Eds: McAlinden, A-M. and Dwyer, C. (London: Hart, 2015: 27-46).

These themes have been well rehearsed in Northern Ireland. As noted above, in the absence of a formal truth process, a patchwork and disaggregated array of measures have been implemented, largely based in the criminal justice system. By way of background, it is helpful to introduce each mechanism at this juncture. The policing approach to the past consists of the Historical Enquiries Team (HET) and the Office of the Police Ombudsman for Northern Ireland (OPONI). The HET was established in 2005 by the former Chief Constable of the Police Service of Northern Ireland (PSNI) Sir Hugh Orde. Its primary objective is to 'assist in bringing a measure of resolution to those families of victims affected by deaths attributed to the troubles in the years 1968-1998' and to chronologically re-examine all 3268 deaths that occurred during this period (HET, undated). Following the investigation, families receive a 'Review Summary Report' which attempts to answer any questions they may have and which details the circumstances of the death and the investigation. Although the unit does gather evidence with a view to prosecution (if deemed viable by the Public Prosecution Service), given the difficulties associated with historical prosecutions, the HET have been careful to manage victims' expectations in this regard (Orde, 2009). By mid 2013, the HET had reopened 2,068 cases which related to the deaths of 2,682 people, and had completed 1,713 cases which related to the deaths of 2,209 people (Healing Through Remembering, 2013). As explored in detail below, the independence and effectiveness of the HET, particularly in respect to its relationship with the PSNI and staffing policies, has been the subject of some critique by academic Patricia Lundy (2009a, 2009b, 2012) and Her Majesty's Inspectorate of Constabulary (2013). Reports on unsolved murders are currently being withheld from victims' families and a date is not available as to the completion of the unit's work (Belfast Telegraph, 2014).

Completing the policing approach to the past is the OPONI, established in 2000 and with the dual mandate of investigating contemporary allegations of police misconduct and historical conflict related cases. While historical cases account for $20 \%$ of the work conducted by the OPONI, they are the most resource intensive and account for most of the public comment and debate that the office attracts. At the time of writing, the Office is reviewing over 150 historical cases, comprising complaints from the public and referrals from the PSNI Chief Constable in relation to deaths and other serious matters believed to have involved members of the former police service, the 
In: Criminal Justice in Transition. Eds: McAlinden, A-M. and Dwyer, C. (London: Hart, 2015: 27-46).

Royal Ulster Constabulary (RUC) ${ }^{4}$ between 1969 and 1998 (OPONI, 2013). Some of those most controversial cases, particularly under the leadership of Nuala O'Loan, include a highly critical report into the RUC/PSNI investigation of the Omagh bombing and the Operation Ballast report which found evidence of collusion between loyalist paramilitary informers and members of the RUC Special Branch (OPONI, 2001, 2007). As with the HET, the OPONI has also faced questions concerning its capacity to deal with historical cases (CAJ, 2011; CJINI, 2011). Detailed below, the cumulative effect of these reports and a damning BBC1 'Spotlight' investigation was the resignation of the former Ombudsman Al Hutchinson and his replacement by Dr. Michael Maguire in July 2012.

At the more 'legal' end of the truth recovery spectrum are public inquiries, a particularly visible form of truth recovery in Northern Ireland. While only those major public inquiries which have occurred during the transitional phase are considered in this chapter, it should be noted that Rolston and Scraton (2005) have documented 23 different types on inquiry into different aspects of state policy during the conflict, and, in the main, dealing with the ways in which the criminal justice system, police and military responded to the campaigns of political violence. Post-conflict, the Saville Inquiry into the events on Bloody Sunday 1972 and the Cory collusion inquiries into the allegations of British state/security force collusion with loyalist paramilitaries in the deaths of Rosemary Nelson, Robert Hamill and Pat Finucane, with republican paramilitaries in the death of Billy Wright and collusion between the IRA and members of An Garda Siochána in the deaths of RUC Chief Superintendent Harry Breen and Superintendent Bob Buchanan are highly significant. The Saville Tribunal reported in June 2010, finding that British Army paratroopers were responsible for causing the deaths of 13 people 'none of whom was posing a threat of causing death or serious injury' (Saville et al, 2010: 58). Public inquiries into the Nelson, Hamill, Wright and Breen/Buchanan cases were also established, and in all but the Hamill case, have reported (see: Morland et al, 2011; MacLean et al, 2010; Smithwick, 2013). A documentary review of the Finucane case was completed in December 2012 (de Silva, 2012). In total, approximately $£ 322$ million has been spent on public inquiries (Healing Through Remembering, 2010; Hilliard, 2013). Calls for further inquiries into the

\footnotetext{
${ }^{4}$ See chapter by Topping in this volume for further discussion on the history of the RUC.
} 
In: Criminal Justice in Transition. Eds: McAlinden, A-M. and Dwyer, C. (London: Hart, 2015: 27-46).

Kingsmills massacre ${ }^{5}$, the Ballymurphy massacre ${ }^{6}$, the Omagh bombing ${ }^{7}$ and the Loughinisland murders $^{8}$ amongst others are ongoing (News Letter, 2010, 2011; Belfast Telegraph, 2012a; BBC, 2013b).

Often described as miniature public inquiries are inquests in the Coroner's courts. As in England and Wales, Coroners in Northern Ireland are required to hold inquests into deaths in order to identify the deceased and to ascertain 'how, when and where the individual died'. ${ }^{9}$ At the time of writing, there are at least 36 conflict related cases in Northern Ireland awaiting inquests. These cases fall into two broad categories: cases which have never had an inquest ('outstanding legacy cases'), largely comprised of deaths involving state actors/agents or allegations of collusion, and cases in which a previous inquest had been completed, but the Attorney General has directed that a new inquest be held - on the grounds of fresh evidence for example (Amnesty International, 2013). ${ }^{10}$ There has been persistent criticism of the operation of the Coroner's system in Northern Ireland (see for example: Ni Aolain, 2000). Prior to the Human Rights Act 1998, much critique was leveled at the lack of breadth of investigation and the findings of inquests, in particular given that Coroners and juries were prohibited from expressing any opinion 'on questions of criminal or civil liability' (Requa and Anthony, 2008; Healing Through Remembering, 2013). Latterly, the inquest system has been criticized for falling short of human rights standards (Anthony and Mageean, 2007). In the McKerr group of cases, the European Court of Human Rights (ECtHR) criticized the lack of verdicts, the absence of legal aid, the non-disclosure of witness statements, the lack of promptness, the inability to compel witnesses, and the limited scope of some inquests. ${ }^{11}$ As a result, the UK government took a number of measures to ensure that future inquests complied with Article 2 of the European Convention on Human Rights

\footnotetext{
${ }^{5}$ On 5 January 1976, 10 Protestant workmen travelling on a minibus were shot dead by members of the Provisional Irish Republican Army (PIRA).

${ }^{6}$ The Ballymurphy massacre refers to a series of incidents between 9-11 August 1971, following the introduction of internment, and during which 11 civilians were killed by members of the Parachute Regiment of the British Army in the Ballymurphy area of west Belfast.

${ }^{7}$ The Real IRA Omagh car bombing of August 1998 killed 29 civilians.

${ }^{8}$ Six men were shot dead by the Ulster Volunteer Force at a bar in Loughinisland, County Down, 18 June 1994.

${ }^{9}$ Coroners Act (Northern Ireland) 1959, s.31(1).

${ }^{10}$ Coroners Act (Northern Ireland) 1959, s.14. At the time of writing, the Attorney General has directed over 30 inquests into conflict related deaths.

${ }^{11}$ See Jordan v UK (2003) 37 EHRR 2; Kelly v UK (Appl No. 30054/96, May 4, 2001); McKerr v UK (2002) 34 EHRR 20; Shanaghan v UK (Appl No. 37715/97, May 4, 2001); Finucane v UK (2003) 37 EHRR 29.
} 
In: Criminal Justice in Transition. Eds: McAlinden, A-M. and Dwyer, C. (London: Hart, 2015: 27-46).

(ECHR) (the right to life), including changes to inquest rules so that witnesses could be compelled and the extension of the scope of an inquest (Amnesty International, 2013). In 2011, the UK Supreme Court also issued a judgment finding that inquests into conflict related deaths were required - as a mater of domestic law - to be Article 2 compliant. ${ }^{12}$ In the judgment, Lady Hale stated, 'differences centre on the scope of the available verdict as to "how" the deceased met his death: in a conventional inquest, "how" means only "by what means" whereas in an Article 2 compliant inquest it must also encompass "in what broad circumstances". ${ }^{13}$ Despite these rulings, concerns remain over endemic delays within the inquest system and over the scope of some inquests, particularly controversial cases involving the use of lethal force by the state and whether such inquests will establish the broader circumstances of a death (Amnesty International, 2013).

The Criminal Cases Review Commission (CCRC) was created by the Criminal Appeal Act 1995 and began work in April 1997. An independent public body, the CCRC investigates alleged miscarriages of justice occurring in the criminal courts and, where appropriate, can refer cases to the Court of Appeal or, where appropriate, the Northern Ireland Court of Appeal (NICA). It has significant legal powers, including the power to access and review police notes or other documents held by public bodies, as well as commission reports from outside bodies. As the CCRC website makes clear, the test that is applied is not whether or not a person is 'innocent', but rather '...to review the cases of those that feel they have been wrongly convicted of criminal offences or unfairly sentenced. We consider whether there is new evidence or argument that may cast doubt on the safety of an original decision'. ${ }^{14}$ Between 1998 and 2011, 33 cases were referred from the CCRC to the Northern Ireland Court of Appeal, 30 of which were conflict related (Healing Through Remembering, 2013). Of these referrals, 26 convictions were quashed. 20 of those cases referred to 'problematic' confessional evidence, including allegations of police torture or other abuses and where juveniles or vulnerable persons had been denied access to their lawyers. At the time of writing, over 30 cases are pending before the CCRC. However, as noted by the CGP (2009),

\footnotetext{
${ }^{12}$ In the matter of an application by Brigid McCaughey and another for Judicial Review (Northern Ireland) [2011] UKSC 20, 18 May 2011.

${ }^{13}$ Ibid, paras [82]-[83].

14 See: webarchive.nationalarchives.gov.uk/20110215111039/http://www.ccrc.gov.uk/about/ about_27.htm. (Accessed on 20 December 2013).
} 
In: Criminal Justice in Transition. Eds: McAlinden, A-M. and Dwyer, C. (London: Hart, 2015: 27-46).

there are potentially hundreds of applications which could be brought to the CCRC by individuals, most of whom were convicted under the Diplock system and which relied heavily on confessional evidence for prosecutions (see: Jackson and Doran, 1995; Dickson, 2010). ${ }^{15}$ As Quirke (2013) points out, in the absence of a formal truth recovery process, criminal appeals are becoming a proxy for addressing the role of the State during the conflict, as well as remedying individual injustices.

In addition to these mechanisms, the use of litigation to seek redress for past injustices or hurts has long been a feature of the Northern Ireland conflict and transition (McEvoy, 2000; Bell and Keenan, 2005; Dickson, 2010). Legal action by both victims and ex-combatants is ongoing. As regards civil action taken by victims, the case taken by some of the families affected by the 1998 Omagh bombing is well known. The civil action began in 2008, and in 2009, republicans Michael McKevitt, Liam Campbell, Colm Murphy and Seamus Daly were found liable for the bombing and were ordered to pay £1.6million in damages. In April 2014, Seamus Daly was charged with 29 counts of murder (BBC, 2014). Legal action by republican and loyalist ex-combatants concerning their internment in the early 1970s is also underway. In August 2011, six former republican detainees served writs on the Ministry of Defence, the Northern Ireland Secretary of State and the police (BBC, 2011a). Charges of trespass of the person, wrongful arrest, unlawful detention and conspiracy to injure are being brought against the British state (UTV, 2011a). Nineteen loyalist ex-combatants are also seeking legal redress for their experiences of internment, again focusing on trauma and human rights violations (Belfast Telegraph, 2012b). Informed by this backdrop, the strengths and weaknesses of utilizing a criminal justice approach to the past in a transitional society are explored below.

\section{The Limitations of Legalism}

McEvoy (2007) argues that the seductive qualities of legalistic analysis lend themselves to transitional contexts and suggests that claims that the 'rule of law' speaks to values and working practices such as justice, objectivity, certainty, uniformity, rationality and so on are particularly prized in times of profound social and political transition. In such contexts, law can become an important practical and symbolic break with the past, a

\footnotetext{
${ }^{15}$ On the Diplock system see chapter by Requa in this volume.
} 
In: Criminal Justice in Transition. Eds: McAlinden, A-M. and Dwyer, C. (London: Hart, 2015: 27-46).

part of the effort to publicly demonstrate the legitimacy and accountability of the new regime (Osiel, 2000; McEvoy, 2007). Yet, as the Northern Ireland case illustrates, there are inherent limits to a legalistic approach to the past in a transitional environment. First, as Campbell and Turner (2008: 376) argue, the 'law "sees" only a limited range of wrongs'. Those typically outside this rubric include issues relating to gender, socioeconomic harm, torture and ill-treatment and the experiences of those injured but not necessarily bereaved by the conflict (de Greiff and Duthie, 2009; Hayner, 2011; CAJ, 2009). Moreover, a legalistic approach to the past, achieved, for example through public inquiries - which will by definition only investigate 'top-line' cases, or inquests or appeals to the CCRC, cannot and is not designed to engage in a broader examination of the causes, context or consequences of a period of political violence, or produce a 'social' or 'restorative' truth (Posel, 1999). Quirke (2013: 952) is persuasive on this point, arguing that ' $[i] \mathrm{t}$ is axiomatic that criminal proceedings are not engaged in a quest for truth, rather they test whether or not the prosecution has established legal guilt to the required standard in accordance with the evidential rules in place'. Writing in respect to the CCRC, Quirke (2013) further illustrates this point, stating that the NICA is not an appropriate route to truth recovery, given that it is not its function, the courts are not prone to self-reflection and that the NICA was itself a protagonist during the conflict. In a similar vein, Rolston and Scraton (2005) have argued that public inquiries can become legalistic vehicles for the obfuscation of truth and minimisation of state culpability. The British government's establishment of the Inquiries Act (2005) that provides for significant ministerial control over the operation of public inquiries and limits the potential for truth telling may be indicative of this point (Requa, 2007).

Rather, the narrative that emerges from a criminal justice approach to the past is a 'micro' or 'forensic' construction of truth (Osiel, 2000). Amnesty International (2013) has clearly made this point in respect to the inquest system, noting that while it is designed to focus on individual cases, questions concerning patterns of violations and abuses and whether state policy or state-sanctioned practices deliberately or indirectly gave rise to unlawful conduct are not being addressed effectively through this mechanism. The Attorney General John Larkin has been similarly careful not to oversell the truth recovery potential of the inquest system in the absence of other measures - 'they cannot, it seems to me, deliver satisfactory outcomes for families 
In: Criminal Justice in Transition. Eds: McAlinden, A-M. and Dwyer, C. (London: Hart, 2015: 27-46).

whose primary wish is to see successful prosecutions, nor can they offer an effective vehicle for the exploration of broader themes and factors that have shaped our recent past' (Larkin, 2012: 15). That the relatives of the 10 individuals killed by members of the British Army in Ballymurphy, west Belfast, August $1971^{16}$, welcomed the announcement that new inquests would be held into the killings, but have publicly stated that they consider them only 'another strand' and continue to demand 'an international independent commission', suggests that at least some victims also recognise these weaknesses (BBC, 2011b). The Northern Ireland Secretary of State has, however, ruled out an independent re-examination of all documents relating to the killings, arguing that such an exercise would not be in the public interest (Moriarty, 2014). A focus on individual responsibility may therefore fail to take proper account of the complex collective factors which contributed to violence and may obscure the broader context of patterns of abuse and systemic wrongdoing over time (McEvoy, 2007; Campbell and Turner, 2008).

Equally, as a matter of practicality, the criminal justice system will only ever be able to look at a limited number of cases. In 2006, for example, Boyd and Doran (2006: 8) raised caution over 'the often harsh realities of proof in context of the criminal trial'. They identified three problems concerning the viability of historical prosecutions - the quality and availability of evidence, and that the range of evidential and procedural protections that are afforded to all suspects of crime may provide difficult barriers for prosecutors to surmount in respect of old cases (Boyd and Doran, 2006). More recently, the Attorney General John Larkin has publicly called to end all conflict related prosecutions, inquests, inquiries and civil actions (Belfast Telegraph, 2013). ${ }^{17}$ Larkin made a number of interlinked arguments - that prosecution is 'subject to a law of diminishing returns' versus the large number of unsolved cases - only three of 1800 cases examined by the HET have resulted in successful convictions, and that the current inquest system (and also public inquiries and the OPONI) is state centric and

\footnotetext{
${ }^{16}$ The British Army has consistently argued that it opened fire in the Ballymurphy area in response to gunfire from republican paramilitaries. The victims' families have continued to protest their innocence. After reviewing the original inquiries, the Attorney General found many weaknesses and unanswered questions and in November 2011 ordered that new inquests be held (UTV, 2011b).

${ }^{17}$ Larkin argued, 'More than 15 years have passed since the Belfast Agreement, there have been very few prosecutions, and every competent criminal lawyer will tell you the prospects of conviction diminish, perhaps exponentially, with each passing year, so we are in a position now where I think we have to take stock' (The Guardian, 2013).
} 
In: Criminal Justice in Transition. Eds: McAlinden, A-M. and Dwyer, C. (London: Hart, 2015: 27-46).

imbalanced in its capacity to deliver truth and justice for victims of state and non-state actors. ${ }^{18}$ While Larkin's proposal was robustly critiqued by victims, political parties and Amnesty International as amounting to an amnesty and denial of justice, that Haass and O'Sullivan (2013) linked the use of limited immunity from prosecution to the proposed ICIR unit arguably represents a pragmatic assessment of the limits of legalism in a transitional setting.

\section{The Meaning of Accountability}

Tied into demands to 'deal with' the past is an increasing international expectation that accountability is due after atrocity (Sikkink, 2011). Key principles of accountability in transitional settings include the need to uncover the truth, the need to restore the honour and reputation of victims and to identify and deal with those responsible for violent acts (Mendez, 1997, cited in Bell, 2003; Hayner 2011). Schabas (2009) argues that a key feature of legalistic debates is a narrow deployment of the term accountability as synonymous with the prosecution and punishment of individual perpetrators of human rights abuses. As detailed above, this can be seen in respect to Northern Ireland's piecemeal and legalistic approach to the past, where accountability for past actions and inactions has been atomized. Clear 'accountability gaps' exist in respect to victims of non-state actors, victims of state human rights violations and, more broadly, in respect to the collective and structural factors which contributed to violence (Bell, 2003; Ni Aolain, 2000).

Yet, as Amnesty International's (2013) report 'Time to Deal with the Past' makes clear, the problems inherent to the piecemeal approach have been exacerbated by serious delays in investigations, concerns about the thoroughness and effectiveness of investigations in some cases, and the independence and impartiality of the HET and OPONI, all of which impacts on the meaning of, and their capacity to deliver, accountability. Criticism of the HET has been well documented. A report by Her Majesty's Inspectorate of Constabulary (HMIC) found, for example, that the HET had

\footnotetext{
${ }^{18}$ Providing some detail on his controversial statement, Larkin noted, '...the State is responsible for a much, much smaller proportion of the deaths that took place during the Troubles. That means that the larger constituency of victims who sustained loss at the hand of non-State actors don't see any comparable tools available to them. They realize that prosecutions are not going to happen at all or, even if they do, their chances of success are limited and the outcome will be a sentence of at most two years' (Belfast Telegraph, 2013).
} 
In: Criminal Justice in Transition. Eds: McAlinden, A-M. and Dwyer, C. (London: Hart, 2015: 27-46).

not maintained its Article 2 required independence because it failed to ensure that former RUC members now working for the unit were not involved in 'state involvement' cases; that cases involving state actors appeared to be treated less rigorously in a number of ways, including how interviews under caution were conducted and the nature and extent of pre-interview disclosure; and the report expressed concern that the lack of any 'public reporting mechanism or accountability structure' other than reporting to the PSNI Chief Constable meant there was 'a real danger that the HET might be inadequate to meet Article 2 standards on transparency and accountability' (HMIC 2013: 26). Likewise, critical reports into the OPONI by the Committee on the Administration of Justice (CAJ) and the Criminal Justice Inspectorate Northern Ireland (CJINI) raised questions of operational independence between the office and the PSNI; a lack of any clear definition or consistent application of the term 'collusion', including that different interpretations could be used depending on the circumstances of the case; and that reports into historical cases were altered or rewritten to exclude criticism of the RUC (CAJ, 2011; CJINI, 2011). While historical investigations have resumed, the current Ombudsman Michael Maguire has acknowledged that the events leading to Al Hutchinson's resignation have seriously damaged public confidence in the Office's capacity to deal with historical cases.

The mechanisms themselves have also been found to have significant weaknesses as regards their capacity to engender truth telling. Lundy (2009a) for example notes that over a period of more than 2.5 years, the HET was unable to trace British soldiers through Ministry of Defence channels. The use of limited immunity in a select number of cases has also been less than persuasive. Bell (2003) points to the Saville Inquiry and notes that while the British state, through the Prime Minister, asserted its commitment to being held to account, in practice, it was difficult to hold military actors accountable. More recently, Judge Smithwick who chaired the investigation into the murder of RUC officers Chief Superintendent Harry Breen and Superintendent Robert Buchanan and the allegation of IRA-Garda collusion, reported that evidence given by former IRA members was dishonest and untruthful (Smithwick, 2013). The former Police Ombudsman Nuala O'Loan (2010) has also documented several instances where police officers gave evasive, contradictory and on occasion farcical answers to questions and senior officers who refused to assist historical 
In: Criminal Justice in Transition. Eds: McAlinden, A-M. and Dwyer, C. (London: Hart, 2015: 27-46).

investigations carried out by her office. The combined effect of these critiques is that existing mechanisms have, or are, falling short of human rights obligations to conduct prompt, thorough and effective investigations in an independent and impartial manner, and that many families of those killed feel their deaths are inadequately investigated or the full truth about the circumstances of their death is not being revealed (CAJ, 2013). At least in respect to several high profile HET investigations such as those into the 1978 IRA La Mon House Hotel bombing and the 1976 PIRA Kingsmill massacre, the reports made available to victims' families appear to have provoked fresh controversy including calls for prosecutions, more inquiries or state apologies (see for example: $\mathrm{BBC}, 2011 \mathrm{c}, 2012)$. Their experience alone suggests that demands for accountability and resolution are not being met by current mechanisms.

\section{Truth and Hierarchies of Victimhood}

As has been well documented, much of the debate on dealing with the past in Northern Ireland has been marked by discussions over 'innocent' and 'guilty' victims and the creation of a 'hierarchy of victimhood' (Smyth, 2007; Brewer, 2010; Brewer and Hayes, 2011). Referring to how the categorization or definition of a victim of the conflict is associated with a political value judgment, a number of concerns regarding current methods of truth recovery and the creation of a hierarchy of victims have been raised (Duffy, 2010).

On one level, the piecemeal approach to the past, realized through the criminal justice system, is, by its very nature, selective and incomplete. The immediate consequence is competition and resentment over the level and depth of historical investigations (CGP, 2009; Commission for Victims and Survivors Northern Ireland (CVSNI), 2012). This concern has been particularly acute amongst unionist political elites and representatives of the security forces, specifically those associated with the Royal Ulster Constabulary. There is, for example, a clear rejection of the 'state-centric' nature of truth recovery and opposition to the selective nature of public inquiries and investigations in the coroners courts, on the grounds that they create a hierarchy of victims, privileging the deaths of those individuals where state involvement is alleged at the expense of the vast majority of those affected by the conflict (Lawther, 2010, 2014). The Saville Inquiry and its financial cost of $£ 195$ million has been a particular 
In: Criminal Justice in Transition. Eds: McAlinden, A-M. and Dwyer, C. (London: Hart, 2015: 27-46).

source of critique (see for example: DUP, 2010). The UUP's Tom Elliott later reemphasized this point in light of the announcement that the PSNI are to carry out a murder inquiry into the events of Bloody Sunday - 'Here we see the hierarchy of victims. Those who received a fully funded public inquiry have the Director of Public Prosecutions as part of setting up a murder investigation. Those whose loved ones died at the hands of terrorists and who have been denied such an Inquiry are not being afforded equality' (UUP, 2012). For representatives of the security forces, a further theme can be identified - that this investigative 'imbalance' is part of a broader attempt to 'blame' the RUC for much of the responsibility for the conflict and to deny their sacrifice (Northern Ireland Retired Police Officers Association, 2008, 2013; Police Federation for Northern Ireland, 2008; Lawther, 2010). As concluded by the CAJ (2013: 8) in their submission to the Haass talks, 'to apply the same mechanism to all deaths would prevent any sense of their being a hierarchy of cases or victims, or that one group or another was being scapegoated'.

Equally concerning is that within the politics of victimhood, certain victim's voices and their calls for truth may be prioritized because of the heavily politicized message they carry, while leaving others at the margins. Such critiques, concerning essentialism and silencing, are not uncommon elsewhere. The SATRC's elevation of the voice of the 'forgiving victim' who directly contributed to the project of national reconciliation is well known (Wilson, 2001; Moon, 2008; Cole, 2010). McEvoy and McConnachie (2013) make the point that voice, or 'the quality of voice' cannot be understood without a keen grasp of how broader political and social narratives are framed (Hamber, 2009: 130). This dynamic can be seen in respect to the presence and absence of victim's voices in Northern Ireland. For example, within republicanism, the notion of 'victimhood as resistance' has a particular currency, whereby calls for truth recovery into high profile cases of suspected collusion have dominated the republican narrative. Brown (2011) argues this is part of an implicit narrative of victimhood within republicanism that privileges paramilitary deaths, particularly where they relate to the purported 'oppression' of the British state, over civilians in commemorative space and narrative. Civilian casualties are more likely to be unnamed, even when killed by accident or in premature explosions caused by republicans themselves (Brown, 2011). There is also little consideration or calls for truth into the cases of approximately 227 
In: Criminal Justice in Transition. Eds: McAlinden, A-M. and Dwyer, C. (London: Hart, 2015: 27-46).

Catholic civilians killed by members of republican paramilitary organisations (Lawther, 2014). As regards unionist political elites, the critique has similarly been made that members of the security forces who died during the conflict occupy a higher position in the hierarchy of victimhood than civilians (Lawther, 2013, 2014). A concurrent critique, made to the author during a period of fieldwork with victims and survivors organisations, is that individual victims have been forgotten in the call for truth and justice into collective tragedies for the unionist community. ${ }^{19}$ Those members of the unionist or loyalist community who are the victims of state collusion also remain missing from this narrative (Dawson, 2007). The available mechanisms and the politics of victimhood have therefore both contributed to perpetuating hierarchies of victimhood and hierarchies of truth in Northern Ireland (Lawther, 2014).

\section{The Capacity of Victims and Ex-Combatants}

The final area this paper considers is the use of law - namely civil litigation by victims and ex-combatants as a route for seeking redress for past injustices (Teitel, 2000). A well-established tradition in Northern Ireland, the resort to law may be viewed as an attempt to 'fix' historical meaning or to shape how events or individuals are remembered (McEvoy, 2000; Osiel, 2000; Bell and Keenan, 2005; Healing Through Remembering, 2006; Dickson, 2010). Moreover, legal processes are often imbued with considerable practical and symbolic importance in broader efforts to uncover and acknowledge unpalatable historical truths (Sarat, 1999; Healing Through Remembering, 2006). As a route to compensation, acknowledgement and/or to uncover or clarify the truth, there is therefore an inevitable 'lure' associated with litigation (Healing Through Remembering, 2013). This can be clearly seen in respect of legal action being taken by former republican and loyalist internees. As detailed above, several charges, including wrongful arrest and unlawful detention, are being brought against the British state. However, represented by solicitor Padraig O Muirigh, the former republican detainees have argued that the importance of an official acknowledgement of the discriminatory nature of internment and the subsequent trauma of human rights violations underpins their case - 'It's not about money, it's really about acknowledgement, officially, that internment was illegal and discriminatory and the

\footnotetext{
${ }^{19}$ This project was entitled 'Assessing Support Initiatives for Victims of Terrorism in the UK and Spain: Lessons for the European Context' and was funded by the European Commission - Directorate-General Justice, Freedom and Security. See: www.victimsofterrorism.co.uk/ (accessed on 11 December 2013).
} 
In: Criminal Justice in Transition. Eds: McAlinden, A-M. and Dwyer, C. (London: Hart, 2015: 27-46).

actions of the government at the time were unlawful' (Irish News, 2011). Those involved in this action also regard their cases to be a litmus test on behalf of almost 2000 people, the majority of whom were members of the Catholic community who were interned without trial between 1971 and 1975 (Irish Times, 2011).

However, civil litigation is often lengthy, complex and financially costly, and with no guarantees that those litigating will achieve their objectives. As has been demonstrated in Northern Ireland, claimants will often face a number of barriers, including delays in proceedings, statutory limitations, evidential burdens and the willingness of other actors, including the State, to disclose information (Healing Through Remembering, 2013). The Omagh case well illustrates these difficulties, given that at the time of writing, Michael McKevitt and Liam Campbell, who, as detailed above, were found liable for the bombing and ordered to pay a share of $£ 1.6$ million in aggravated damages, are in the process of taking their case to the European Court of Human Rights in an attempt to avoid paying damages (Barrett and Sawer, 2014). While speaking clearly to the tenacity and energy of some of the victims, as this case illustrates, there are no guarantees of success even after years of litigation and the emotional, personal and financial investment is often considerable. ${ }^{20}$ Doubt has also been cast on the capacity of a lawsuit for damages to serve as a vehicle for truth recovery. British Irish Rights Watch (2012) has picked up on this point in respect of the Omagh case, arguing that it 'might attribute culpability but can establish little more than that in relation to delivering answers which might salve a quest for justice and closure'. Moreover, in practical terms, the Department of Justice for Northern Ireland (DoJNI) has recently closed a consultation on the remuneration of civil legal aid, in which it was proposed that a revised fee structure be introduced, involving standard fees for civil cases (DoJNI, 2013). One objective is to make approximately $£ 5$ million in savings from the legal aid budget (DoJNI, 2013). If implemented, the reforms could potentially restrict the availability of legal aid in civil litigation cases involving the past. Collectively, these barriers are likely to prevent the majority of those affected by the conflict from being able to pursue their objectives of retributive justice,

\footnotetext{
${ }^{20}$ Moreover, for those families whose cases do not lend themselves to legal challenge or who do not have the necessary campaigning or political support structures, their need for truth recovery remains unaddressed, leading the former Chief Constable of the PSNI Sir Hugh Orde (2005: 3) to argue 'It [litigation] lends itself to a survival of the fittest phenomenon since it delivers results for those high profile cases which stay the course or attract the most media or political attention'.
} 
In: Criminal Justice in Transition. Eds: McAlinden, A-M. and Dwyer, C. (London: Hart, 2015: 27-46).

acknowledgement, compensation or truth through the courts alone (Healing Through Remembering, 2013).

\section{Conclusion}

This chapter has critically engaged with the criminal justice approach to the past in Northern Ireland's transitional setting. As noted above, some notable successes have stemmed from, for example, public inquiries, the HET and the CCRC. In such cases, some measure of truth, accountability and resolution has been delivered. Yet, as Quirke (2013: 952) argues in respect of the CCRC, in the transitional context, '... such cases are being dealt with by an institution that was designed to meet the needs of ordinary criminal justice in settled democracy, rather than the exceptionalist institutions, such as truth commissions or amnesty processes, commonly associated with transitional justice'. Borne out by the weaknesses and hurdles faced by victims and ex-combatants who attempt to bring civil actions, the highly selective nature of public inquiries, significant delays in the coronial system and the now tarnished HET and OPONI - both of which inadvertently became 'the' vehicles for truth recovery, Quirke's (2013) comments resonate more broadly. As I have argued above, given the absence of a viable alternative, the criminal justice approach to the past in Northern Ireland has resulted in a process that is piecemeal, overtly legalistic, offers a weak form of accountability and has fed into hierarchal notions of victimhood. It is also crumbling under the weight of historical investigations and contested notions of the past.

A number of significant issues remain outstanding. One, as highlighted in a recent CJINI (2013) publication, the current approach to the past is financially punishing, with particular pressure on the PSNI (Lawther, 2010). Secondly, the available mechanisms cannot deliver a consistent or comprehensive level of truth recovery, with gaps in investigative measures meaning different agencies passing cases to and fro, and resulting in some victims' families falling through the gaps and others having to engage with various processes over a considerable period of time (CAJ, 2013). The failure to properly investigate by conducting prompt, thorough and effective investigations in an independent and impartial manner is also a violation of human rights standards (Bell and Keenan, 2005). Moreover, as Hayner (2011), Posel (1999) and others have argued, post-conflict, there is a need to move beyond individualized, 
In: Criminal Justice in Transition. Eds: McAlinden, A-M. and Dwyer, C. (London: Hart, 2015: 27-46).

micro truths to a social and more 'restorative' truth. As yet, the existing mechanisms are neither designed nor equipped to develop a comprehensive understanding of the extent and patterns of violations, or the causes, consequences and context of the conflict. Lacking an overall narrative of the events of the past 40 years, the net effect is that every contest in the peace process becomes a surrogate of the conflict, leading to an endless replay of the meta-conflict (Bell et al, 2004). This final point also resonates more broadly. As is the aim of this book, the Northern Ireland case study has much to offer other transitional jurisdictions. The international literature on transitional justice and human rights points to the centrality of rebuilding the structures and mechanisms of state justice and moving on from the legacy of an abusive past (see for example: Teitel, 2000; Roht-Arriaza and Mariezcurrena, 2006; Olsen et al, 2010). The transitional justice 'tool-kit' - composed of mechanisms such as truth commissions, inquiries, apologies and reparations programmes, is united by the themes of truth, justice, accountability and acknowledgement. As this chapter has argued, if transitional societies, such as Northern Ireland, are to realize these objectives and deal with their past in a meaningful and effective manner, there is a need for greater creativity beyond a purely criminal justice approach to the past.

\section{Bibliography}

Amnesty International (2013) Northern Ireland: Time to Deal with the Past (London, Amnesty International Ltd).

Anthony, G and Mageean, P (2007) 'Habits of Mind and 'Truth Telling': Article 2 ECHR in Post Conflict Northern Ireland', in J Morison, K McEvoy, and G Anthony (eds) Judges, Human Rights and Transition: Essays in Honour of Stephen Livingstone (Oxford, Oxford University Press).

Barrett, D and Sawer, P (2014) 'Omagh bombing: Real IRA terrorists appeal to European Court', The Telegraph, 19 April 2014.

BBC (2011a) 'Republicans 'To Sue Government' over Northern Ireland Internment', BBC News, 9 August 2011. Available at: http://www.bbc.co.uk/news/uk-northern-

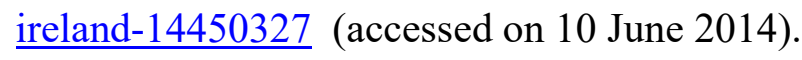


In: Criminal Justice in Transition. Eds: McAlinden, A-M. and Dwyer, C. (London: Hart, 2015: 27-46).

BBC (2011b) 'Ballymurphy families welcome John Larkin decision', BBC News, 15 November 2011. Available at: http://www.bbc.co.uk/news/uk-northern-ireland15731558 (accessed on 10 September 2014).

BBC (2011c) 'Kingsmills families demand full inquiry into massacre', BBC News, 21 June 2011. Available at: http://www.bbc.co.uk/news/uk-northern-ireland-13857495 (accessed on 10 September 2014).

BBC (2012) 'La Mon IRA bomb victims want public inquiry after HET report', $B B C$ News, 16 February 2012. Available at: http://www.bbc.co.uk/news/uk-northernireland-17061713 (accessed on 10 September 2014).

BBC (2013a) 'Northern Ireland: Richard Haass talks end without deal', $B B C$ News, 31 December 2013. Available at: http://www.bbc.co.uk/news/uk-northern-ireland$\underline{25556714}$ (accessed on 10 September 2014).

BBC (2013b) 'Omagh bomb families make new call for inquiry', BBC News, 8 August 2013. Available at: http://www.bbc.co.uk/news/uk-northern-ireland-23607106 (accessed on 10 September 2014).

BBC (2014) 'Omagh bomb: Seamus Daly charged with 29 murders', BBC News, 10 April 2014. Available at: http://www.bbc.co.uk/news/uk-northern-ireland-26976719 (accessed on 10 September 2014).

Belfast Telegraph (2012a) 'Rally Calls for Inquiry into Ballymurphy Killings by Soldiers', Belfast Telegraph, 13 August 2012.

Belfast Telegraph (2012b) 'Kenya move 'boosts internment case”, Belfast Telegraph, 5 October 2012.

Belfast Telegraph (2013) 'Attorney General John Larkin: it's time to call halt to all Troubles cases', Belfast Telegraph, 20 November 2013. 
In: Criminal Justice in Transition. Eds: McAlinden, A-M. and Dwyer, C. (London: Hart, 2015: 27-46).

Belfast Telegraph (2014) 'Unsolved Troubles murder reports to be withheld until future of Historical Enquiries Team sorted', Belfast Telegraph, 15 January 2014.

Bell, C (2003) 'Dealing with the Past in Northern Ireland', 26 Fordham International Law Journal 1095.

Bell, C, Campbell, C and Ni Aolain, F (2004) 'Justice Discourses in Transition', 13 Social and Legal Studies 305.

Bell, C and Keenan, J (2005) 'Lost on the Way Home: The Right to Life in Northern Ireland', 32 Journal of Law and Society 68.

Boraine, A (2000) A Country Unmasked: Inside South Africa's Truth and Reconciliation Commission (Oxford, Oxford University Press).

Boyd, D and Doran, S (2006) The Viability of Prosecution Based on Historical Enquiry. Observations of Counsel on Potential Evidential Difficulties (Belfast, Healing Through Remembering).

Brewer, J (2010) Peace Processes: A Sociological Approach (Cambridge, Polity).

Brewer, J and Hayes, B (2011) 'Victims as moral beacons: victims and perpetrators in Northern Ireland', 6 Contemporary Social Science 73.

British Irish Rights Watch (2012) Consultation: Justice and Security Green Paper (October 2011) CM 8194 (London, British Irish Rights Watch).

Brown, K (2011) 'Rights and victims, martyrs and memories: the European Court of Human Rights and political transition in Northern Ireland', in M Hamilton and A Buyse (eds) Transitional Jurisprudence and the ECHR. Justice, Politics and Rights (Cambridge: Cambridge University Press). 
In: Criminal Justice in Transition. Eds: McAlinden, A-M. and Dwyer, C. (London: Hart, 2015: 27-46).

Campbell, C and Turner, C (2008) 'Utopia and the doubters: truth, transition and the law', 28 Legal Studies 374.

Cole, C (2010) Performing South Africa's Truth Commission: Stages of Transition (Bloomington, I.A, Indiana University Press).

Commission for Victims and Survivors Northern Ireland (2012) Comprehensive Needs Assessment (Belfast, Commission for Victims and Survivors Northern Ireland).

Committee on the Administration of Justice (2009) Response to the Consultation on the Report of the Consultative Group on the Past (Belfast, Committee on the Administration of Justice).

Committee on the Administration of Justice (2011) Human Rights and Dealing with Historic Cases - A Review of the Office of the Police Ombudsman for Northern Ireland (Belfast, Committee on the Administration of Justice).

Committee on the Administration of Justice (2013) Dealing with the Past: Investigating Troubles-Related Deaths: Submission to the multi-party group chaired by Richard Haass (Belfast, Committee on the Administration of Justice).

Consultative Group on the Past (2009) Report of the Consultative Group on the Past (Belfast, Consultative Group on the Past).

Criminal Justice Inspection Northern Ireland (2011) An Inspection into the Independence of the Office of the Police Ombudsman for Northern Ireland (Belfast, Criminal Justice Inspection Northern Ireland).

Criminal Justice Inspection Northern Ireland (2013) A Review of the Cost and Impact of Dealing with the Past on Criminal Justice Organisations in Northern Ireland (Belfast, Criminal Justice Inspection Northern Ireland). 
In: Criminal Justice in Transition. Eds: McAlinden, A-M. and Dwyer, C. (London: Hart, 2015: 27-46).

Dawson, G (2007) Making Peace with the Past? Memory, trauma and the Irish Troubles (Manchester, Manchester University Press).

de Greiff, P and Duthie, R (2009) Transitional Justice and Development: Making Connections (New York, Social Science Research Council).

Democratic Unionist Party (2010) 'Inquiries have created hierarchy of victims Campbell', Press Release, 15 June 2010.

Department of Justice Northern Ireland (2013) Consultation Document: Civil Legal Aid Remuneration (Belfast, Department of Justice Northern Ireland).

Dickson, B (2010) The European Convention on Human Rights and the Conflict in Northern Ireland (Oxford, Oxford University Press).

Duffy, A (2010) ‘A Truth Commission for Northern Ireland?', 4 International Journal of Transitional Justice 26.

Hamber, B (2009) Transforming Societies after Political Violence. Truth, Reconciliation and Mental Health (New York, Springer).

Haass, R and O'Sullivan, M (2013) An Agreement among the Parties of the Northern Ireland Executive on Parades, Select Commemorations, and Related Protests; Flags and Emblems; and Contenting with the Past. Online. Available at: www.northernireland.gov.uk/haass.pdf (Accessed on 17 January 2014).

Hayner, P (2011) Unspeakable Truths: Transitional Justice and the Challenge of Truth Commissions (London, Routledge).

Healing Through Remembering (2006) Making Peace with the Past: Options for truth recovery regarding the conflict in and about Northern Ireland (Belfast, Healing Through Remembering). 
In: Criminal Justice in Transition. Eds: McAlinden, A-M. and Dwyer, C. (London: Hart, 2015: 27-46).

Healing Through Remembering (2010) Paper on Dealing with the Past: Costs to Date and for 2010-2014 (Belfast, Healing Through Remembering).

Healing Through Remembering (2013) Dealing with the Past? An Overview of Legal and Political Approaches Relating to the Conflict in and about Northern Ireland (Belfast, Healing Through Remembering).

Her Majesty's Inspectorate of Constabulary (2013) Inspection of the Police Service of Northern Ireland Historical Enquiries Team (London, Her Majesty's Inspectorate of Constabulary).

Hilliard, M (2013) ‘Smithwick Tribunal report: costs incurred run to $€ 15$ million', Irish Times, 4 December 2013.

Historical Enquiries Team (undated) Policing the Past. Introducing the work of the Historical Enquiries Team (Belfast, Police Service of Northern Ireland).

Irish News (2011) 'Government paper discovery sparks internment test case', Irish News, 9 August 2011.

Irish Times (2011) 'Former detainees bring internment case', Irish Times, 10 August 2011.

Jackson, J and Doran, S (1995) Judge without Jury. Diplock Trials in the Adversary System (Oxford, Oxford University Press).

Larkin, J (2012) Attorney General for Northern Ireland: Second Annual Report. 2011/12. Available at: Www.attorneygeneralni.gov.uk/annual_report_201112_final_.pdf (Accessed on 19 December 2013).

Lawther, C (2010) “Securing' the Past: Policing and the Contest over Truth in Northern Ireland', 50 British Journal of Criminology 455. 
In: Criminal Justice in Transition. Eds: McAlinden, A-M. and Dwyer, C. (London: Hart, 2015: 27-46).

Lawther, C (2013) 'Denial, Silence and the Politics of the Past: Unpicking the Opposition to Truth Recovery in Northern Ireland', 7 International Journal of Transitional Justice 157.

Lawther, C (2014) Truth, Denial and Transition: Northern Ireland and the Contested Past (London, Routledge).

Lundy, P (2009a) 'Can the Past be Policed? Lessons form the Historical Enquiries Team Northern Ireland', 11 Law and Social Challenges 109.

Lundy, P (2009b) 'Exploring Home-Grown Transitional Justice and Its Dilemmas: A Case Study of the Historical Enquiries Team, Northern Ireland', 3 International Journal of Transitional Justice 321.

Lundy, P (2010) 'Commissioning the Past in Northern Ireland', 1138 Review of International Affairs 101.

Lundy, P (2012) Research Brief: Assessment of the Historical Enquiries Team (HET) Review Processes and Procedures in Royal Military Police (RMP) Investigation Cases. Available at: www.socsci.ulst.ac.uk/sociology/profiles/p.lundy/research.phtml (Accessed on 14 May 2013).

Lundy, P and McGovern, M (2008) 'Truth, Justice and Dealing with the Legacy of the Past in Northern Ireland', 7 Ethnopolitics 117.

MacLean, R, Coyle, A and Oliver, J (2010) The Billy Wright Inquiry Report (London, The Stationary Office).

McEvoy, K (2000) 'Law, Struggle and Political Transformation in Northern Ireland', 27 Journal of Law and Society 542.

McEvoy, K (2007) 'Beyond Legalism: Towards a Thicker Understanding of Transitional Justice', 34 Journal of Law and Society 411. 
In: Criminal Justice in Transition. Eds: McAlinden, A-M. and Dwyer, C. (London: Hart, 2015: 27-46).

McEvoy, K and McConnachie, K (2013) 'Victims and Transitional Justice: Voice, Agency and Blame', 22 Social and Legal Studies 489.

McKittrick, D, Kelters, S, Feeney, B, Thornton, C and McVea, D (2007) Lost Lives: The Stories of the Men, Women and Children who Died as a Result of the Northern Ireland Troubles (Edinburgh, Mainstream).

Misztal, B (2003) Theories of Social Remembering (Open University Press, Maidenhead).

Moon, C (2008) Narrating Political Reconciliation. South Africa's Truth and Reconciliation Commission (Plymouth, Lexington Books).

Moriarty, G (2014) 'Villiers rejects call for Ballymurphy inquiry', The Irish Times, 29 April 2014.

Morland, M, Strachan, V and Burden, A (2011) The Rosemary Nelson Inquiry Report (London, The Stationary Office).

News Letter (2010) 'Call for public inquiry into UVF massacre', News Letter, 25 November 2010.

News Letter (2011) 'Kingsmills families want killers named', News Letter, 22 June 2011.

Ni Aolain, F (2000) The politics of force: conflict management and state violence in Northern Ireland (Belfast, Blackstaff).

Northern Ireland Office (2013) 'Dr. Richard Haass to Chair All-Party Talks', Press Release, 9 July 2013. 
In: Criminal Justice in Transition. Eds: McAlinden, A-M. and Dwyer, C. (London: Hart, 2015: 27-46).

Northern Ireland Retired Police Officers Association (2008) Submission to the Consultative Group on the Past (Belfast, Northern Ireland Retired Police Officers Association).

Northern Ireland Retired Police Officers Association (2013) Written Submission by the Northern Ireland Retired Police Officers Association to Dr. Richard Haass on "Dealing with the Past" (Belfast, Northern Ireland Retired Police Officers Association).

O'Loan, N (2010) 'The Police Ombudsman for Northern Ireland: some reflections' in J Doyle (ed) Policing the Narrow Ground: Lessons from the transformation of policing in Northern Ireland (Dublin: Royal Irish Academy).

O'Rawe, M (2003) 'Transitional Policing Arrangements in Northern Ireland: The Can't and The Won't of the Change Dialectic', 26 Fordham International Law Journal 1015.

Office of the Police Ombudsman for Northern Ireland (2001) Statement by the Police Ombudsman for Northern Ireland on her Investigation of Matters Relating to the Omagh Bombing on August 151998 (Belfast, Office of the Police Ombudsman for Northern Ireland).

Office of the Police Ombudsman for Northern Ireland (2007) Statement by the Police Ombudsman for Northern Ireland on her investigation into the circumstances surrounding the death of Raymond McCord Junior and related matters (Belfast, Office of the Police Ombudsman for Northern Ireland).

Office of the Police Ombudsman for Northern Ireland (2013) Annual Business Plan 2012-2013.

Available at: http://www.policeombudsman.org/Publicationsuploads/201314\%20Annual\%20Business\%20Plan\%20(web).pdf (accessed on 10 June 2014).

Olsen, T, Payne, L and Reiter, G (2010) Transitional Justice in Balance: Comparing Processes, Weighing Efficacy (Washington: United States Institute of Peace Press). 
In: Criminal Justice in Transition. Eds: McAlinden, A-M. and Dwyer, C. (London: Hart, 2015: 27-46).

Orde, H (2005) 'War is easy to declare, peace is an elusive prize', Paper presented at the Telling the Truth in Ireland Conference, Dublin: Trinity College Dublin.

Orde, H (2009) 'War is easy. Peace is the difficult prize'. Longford Lecture, The Longford Trust. Available at:

www.longfordtrust.org/lecture_details.php?id=6\&page=3 (Accessed on 19 December 2013).

Osiel, M (2000) Mass Atrocity, Collective Memory and the Law (London, Transaction Publishers).

Police Federation for Northern Ireland (2008) Submission by the Police Federation for Northern Ireland to the Consultative Group on the Past (Belfast, Police Federation for Northern Ireland).

Posel, D (1999) 'The TRC Report: What Kind of History? What Kind of Truth?' in D Posel and G Simpson (eds) Commissioning the Past. Understanding South Africa's Truth and Reconciliation Commission (Johannesburg: Witwatersrand University Press).

Quirke, H (2013) 'Don't Mention the War: The Court of Appeal, the Criminal Cases Review Commission and Dealing with the Past in Northern Ireland', 76 The Modern Law Review 949.

Requa, M (2007) 'Truth, Transition and the Inquiries Act 2005', 4 European Human Rights Law Review 404.

Requa, M and Anthony, G (2008) 'Coroners, Controversial Deaths and Northern Ireland's Past Conflict', 62 Public Law 443.

Roht-Arriaza, N and Mariezcurrena, J (2006) Transitional Justice in the Twenty-First Century: Beyond Truth versus Justice (Cambridge: Cambridge University Press). 
In: Criminal Justice in Transition. Eds: McAlinden, A-M. and Dwyer, C. (London: Hart, 2015: 27-46).

Rolston, B and Scraton, P (2005) 'In the full glare of English politics: Ireland, Inquiries and the British state,' 45 British Journal of Criminology 547.

Sarat, A (1999) 'The Necessity and Challenges of Establishing a Truth and Reconciliation Commission in Rwanda', 21 Human Rights Quarterly 761.

Saville, M, Hoyt, W and Toohey, J (2010) Report of the Bloody Sunday Inquiry (London, The Stationary Office).

Schabas, W (2009) Genocide in International Law: The Crime of Crimes (Cambridge, Cambridge University Press).

de Silva, D (2012) The Report of the Patrick Finucane Review (London, The Stationary Office).

Sikkink, K (2011) The Justice Cascade: How Human Rights Prosecutions are Changing World Politics (New York, N.W. Norton and Company Inc).

Smithwick, P (2013) Report of the Tribunal of Inquiry into Suggestions that Members of An Garda Siochana or other Employees of the State colluded in the Fatal Shootings of RUC Chief Superintendent Harry Breen and RUC Superintendent Robert Buchanan on the $20^{\text {th }}$ March 1989 (Dublin, The Stationery Office).

Smyth, M (2007) Truth Recovery and Justice After Conflict. Managing Violent Pasts (London, Routledge).

Teitel, R (2000) Transitional Justice (Oxford, Oxford University Press).

The Guardian (2013) 'Northern Ireland attorney general calls for end to Troubles prosecutions', The Guardian, 20 November 2013.

Tutu, D (1999) No Future Without Forgiveness (London, Rider). 
In: Criminal Justice in Transition. Eds: McAlinden, A-M. and Dwyer, C. (London: Hart, 2015: 27-46).

UTV (2011a) 'Legal writ served over internment', UTV News, 9 August 2011. Available at: http://www.u.tv/articles/article.aspx?cat=news\&guid=8b2a9929-fc674f06-ac88-5a5b4f58eeee (accessed on 10 September 2014).

UTV (2011b) 'New Inquests into Ballymurphy deaths', UTV News, 14 November 2011. Available at: $\quad$ http://www.u.tv/News/New-inquests-into-Ballymurphydeaths/6c0fe56b-19fa-42a1-af0d-b39e4903ef5b (accessed on 10 September 2014).

Ulster Unionist Party (2012) 'Elliott shocked at news of Bloody Sunday murder inquiry', Press Release, 7 May 2012.

Wiebelhaus-Brahm, E (2010) Truth Commissions and Transitional Societies. The impact on human rights and democracy (London, Routledge).

Wilson, R (2001) The Politics of Truth and Reconciliation in South Africa: Legitimizing the Post-Apartheid State (Cambridge, Cambridge University Press). 